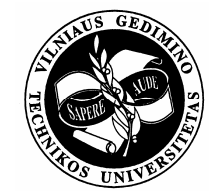

\title{
HYDROLOGICAL RESPONSE TO LAND USE CHANGES IN CENTRAL EUROPEAN LOWLAND FOREST CATCHMENTS
}

\author{
Bernard Okoński \\ Dept of Forest Engineering, August Cieszkowski Agricultural University of Poznań, \\ Mazowiecka 41,60-623 Poznań, Poland.E-mail: okonski@au.poznan.pl \\ Submitted 14 Apr 2006; accepted 11 Nov 2006
}

\begin{abstract}
The influence of forest environment characteristics especially forest vegetation and soil are the main causative, non-climatic agents shaping water processes in forest ecosystems. The impact of land cover changes on direct runoff from a forest catchment was examined. Hydrological modeling was employed. The runoff module of the model was cascade of linear reservoir solution. The rainfall separation module is based on the SCS-CN method altered by means of a unique methodology. Thus, the main investigation effort was applied to work out a methodological solution. The model was tested in a lowland forest catchment located in the Polish part of Central European Plain. Calibration was performed for the current cover state along with simulation for 9 hypothetical cases and a case based on reconstruction of the historic state of land cover. The cases of land cover state were developed on the basis of qualitative and/or quantitative vegetation property changes.
\end{abstract}

Keywords: rainfall-runoff modeling, direct runoff, SCS-CN method, forest catchment, land cover changes.

\section{Introduction}

Water processes observed on areas covered with forests usually differ distinctively from those occurring on other, sometimes superficially similar, agricultural sites. Hydrological processes are dependant on biomass filling in forest ecosystems which is a forest habitat characteristic. Thus, all the hydrological processes proceeding there are shaped directly or indirectly by forest vegetation and ecological processes modulated by forest vegetation [1, 2]. Although until recently a substantial amount of research has been done to explain the issues related to forest ecosystem-hydrological process interaction, nevertheless, many questions still need answers and further explanation. Especially acute need is desired for establishment of a firmer quantitative description of forest environment characteristics (forest stand, forest site characteristics) impact on particular hydrologic balance elements [3]. The progress in the area could help to put more exactness into modeling of hydrologic processes on forest areas [4]. Then models would be created rather on the basis of physical processes than on conceptual dependences $[5,6]$. The current state of knowledge results in that most of the hydrological models employed in rainfallrunoff modeling are conceptual or semi-conceptual solutions. Although these relatively simple models are built on an assumption that not all the dependences can be described with a thorough knowledge of physical nature of related processes, nevertheless, these models are still successfully used, especially for operational purposes. A practical problem arising due to that limitation is scarcity of runoff modeling methodologies strictly dedicated for forest areas. Universal models (typically developed for agricultural or natural catchments) should be usually modified or adopted [6]. Regardless of the above mentioned limitations, the issue of land use changes impact on runoff modeling seems to have been gaining still an increasing scientific attention [7-10].

A forest ecosystem is fairly a dynamic environment. Some physiographic characteristics are stable over time (e g mechanical soil characteristics), otherwise those related to forest vegetation change relatively quickly. Forest vegetation character tends to change due to natural processes (eg maturing of forest stand, natural dying back of certain tree species) or impact of man-caused actions (e $g$ forest management activities) and negative undesired side effects (air pollution, forest grazing, etc) [1, 4].

The state of a forest ecosystem, quantified by stand and site characteristics, affects the processes of rainfall transformation into runoff in a catchment. The amount of rainfall water transformed into runoff also depends on the quality of vegetation. As far as a forest ecosystem is concerned important factors are, e g species composition, forest density and age, vertical structure of forest stand, type of forest litter [11].

Definitely, leading significance in rainfall-runoff transformation should be ascribed to forest quantity - the proportion as well as distribution of forest cover in a catchment [11]. Natural vegetation of Central Europe is mainly composed of forests. Although land cover pattern has changed there over centuries, forest and wooded cover currently represents no less than $30 \%$ of the area of each Central European country. Generally, deforestation processes have prevailed in this part of Europe until re- 
cently. Cleared land was usually left for agricultural purposes. This general direction of land cover change depended on many economic, social and political factors and progressed with various intensity in the past [12]. In recent times, the deforestation process has been stopped and reverted. Many areas, especially these on less fertile soils or with unfavorable relief and climatic conditions, have been reforested (e $\mathrm{g}$ in Germany the process started even as early as $19^{\text {th }}$ century, in Poland after WWII forest land cover rose by $40 \%$ ). Rainfall-runoff process pattern have certainly changed in many catchments affected by these land cover changes. includes:

The scope of investigation described in this paper

1. development of modeling methodology for determining runoff amount as influenced by state of vegetation in forest catchments;

2. assessment of runoff volume for a hypothetical state of land cover in a forest catchment (formed as a result of quantitative or qualitative changes of vegetation).

Thus, the main investigation effort was applied to work out a methodological solution. The framework applied to achieve this goal was one of the existing conceptions, namely SCS-CN method.

\section{Methodology}

\subsection{General modeling methodology}

The model employed for runoff-rainfall process simulation was based on bi-modular conceptual solution. The module used for determination of effective rainfall out of the total rainfall was SCS-CN method. The existing standard form of SCS-CN method was modified in the course of investigation and adopted to include the properties of local physiographic conditions, mainly forest vegetation characteristics modulated by climate. These properties were quantified and parameterized according to both the principles of SCS-CN methodology and generally recognized relationships ruling over rainfall separation. The module employed for generation of direct runoff was a cascaded linear reservoir model. A general scheme of the model is presented in Fig 1.

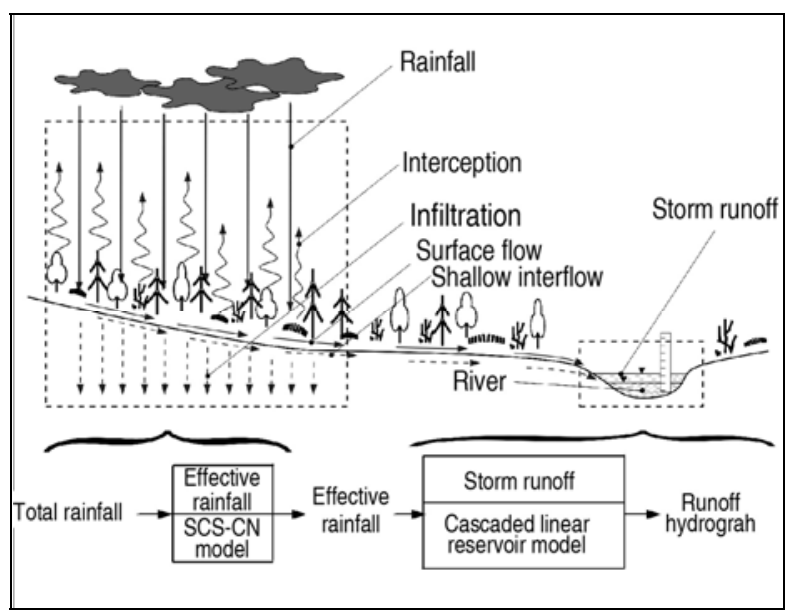

Fig 1. Block diagram of the rainfall-runoff model

\subsection{Direct runoff module}

The linear reservoir model employed for the purpose of this work is described below.

In general, the cascade of linear reservoir model is based on the conception of Instantaneous Unit Hydrograph (IUH) - runoff hydrograph is built as a sum of superposed unit hydrographs induced by unit rainfall [13]. This well-established conception is widly used for hydrological modeling [14]. The variation of the model developed for the investigation herein described was a solution with linear reservoirs applied as components of model structure (Fig 2).

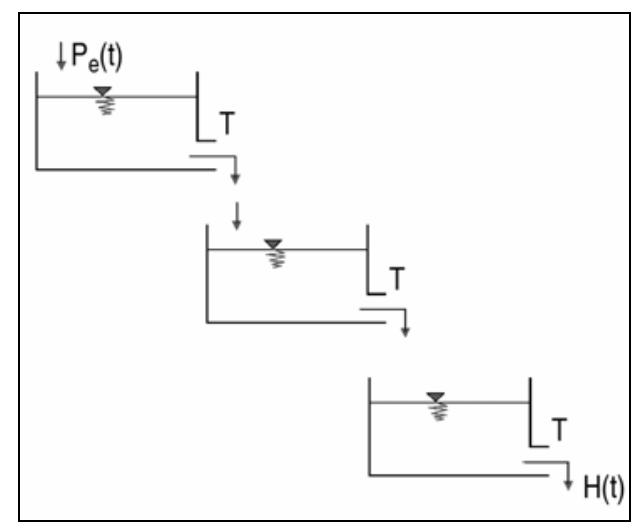

Fig 2. Scheme of Nash model (the cascade of $\mathrm{N}$ linear reservoirs of constant moments $\mathrm{T}$ )

The hydrological system is thus presented as a cascade of linear reservoirs with two key parameters: constant moment $(\mathrm{T})$ and the number of reservoirs $(\mathrm{N})$.

In general, the model can be described as follows:

1. Continuity equation:

$$
\frac{d R}{d t}=P_{e}(t)-H(t)
$$

where $R(t), P_{e}(t), H(t)$ - respectively, retention, effective rainfall and runoff in moment $T$,

2. Storage equation:

$$
R(t)=f\left(P_{e}(t), \frac{d P_{e}}{d t}, \ldots, \frac{d^{m} P_{e}}{d^{m} t}, H(t), \frac{d H}{d t}, \ldots, \frac{d^{n} H}{d^{n} t}\right),
$$

where $R(t), P_{e}(t), H(t)$ - as above.

3. Transmitation equation:

$$
H(t)=G\left[P_{e}(t)\right],
$$

where $P_{e}(t), H(t)$ - as above, $G$ - transmitation operator.

Applying operator transmitation for Nash model:

$$
G(s)=(T \cdot s+1)^{-N} \text {. }
$$

Then using inverse Laplace transformation:

$$
g(t)=\frac{1}{T^{N}} \cdot e^{-\frac{t}{T}} \cdot \frac{1}{\Gamma(N)} \cdot t^{N-1}[15],
$$

where $g(t)$ - Instantaneous Unit Hydrograph (IUH); $\Gamma(\mathrm{N})$ - the Gamma function, for natural $\mathrm{N} \Gamma(\mathrm{N})=(\mathrm{N}-1)$ !.

For $\mathrm{N}=1,2,3$ respective cascade transmitations are: 


$$
\begin{gathered}
G_{1}(s)=\frac{1}{T \cdot s+1}, G_{2}(s)=\frac{1}{(T \cdot s+1)^{2}}, \\
G_{3}(s)=\frac{1}{(T \cdot s+1)^{3}} .
\end{gathered}
$$

Response for unit impulse is (Fig 3):

$$
\begin{gathered}
P e_{1}(t)=\left\{\begin{aligned}
0 & \text { for } t<0 \quad \text { it } t>1 \\
1 & \text { for } 0<t<1 \\
1 / 2 & \text { for } t=0 \quad i t=1
\end{aligned}\right. \\
P e_{1}(t)=\eta(t)-\eta(t-1),
\end{gathered}
$$

where $\eta(t)$ - Heaviside step function unit step function.

Laplace transformation for $P_{e 1}(t)$ is:

$$
P e_{1}(s)=\frac{1}{s} \cdot\left(1-e^{-S}\right)[16]
$$

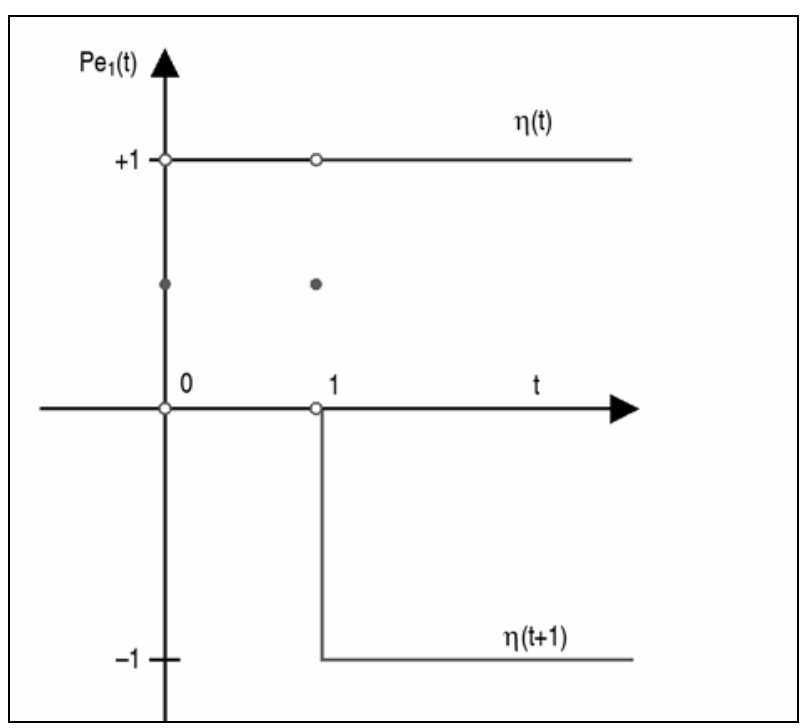

Fig 3. Unit impulse

Thus, corresponding transformations of response are:

then

$$
\begin{aligned}
& H_{11}(s)=G_{1}(s) \cdot P e_{1}(s), \\
& H_{12}(s)=G_{2}(s) \cdot P e_{1}(s), \\
& H_{13}(s)=G_{3}(s) \cdot P e_{1}(s),
\end{aligned}
$$

$$
\begin{gathered}
H_{11}(s)=\frac{1}{T \cdot s+1} \cdot \frac{1}{s} \cdot\left(1-e^{-S}\right), \\
H_{12}(s)=\frac{1}{(T \cdot s+1)^{2}} \cdot \frac{1}{s} \cdot\left(1-e^{-S}\right), \\
H_{13}(s)=\frac{1}{(T \cdot s+1)^{3}} \cdot \frac{1}{s} \cdot\left(1-e^{-S}\right) .
\end{gathered}
$$

If substituting inverse Laplace transformation for equations (9), (10) and (11) the response equations are: $H_{11}(t)=L^{-1}\left[\frac{1}{T \cdot s+1} \cdot \frac{1}{s} \cdot\left(1-e^{-S}\right)\right]=e^{-\frac{t-1}{T}}-e^{-\frac{t}{T}} ;(N=1)$,

$$
\begin{array}{r}
H_{12}(t)=L^{-1}\left[\frac{1}{(T \cdot s+1)^{2}} \cdot \frac{1}{s} \cdot\left(1-e^{-S}\right)\right]= \\
\left(1+\frac{t-1}{T}\right) \cdot e^{-\frac{t-1}{T}}-\left(1+\frac{t}{T}\right) \cdot e^{-\frac{t}{T}} ;(N=2), \\
H_{13}(t)=L^{-1}\left[\frac{1}{(T \cdot s+1)^{3}} \cdot \frac{1}{s} \cdot\left(1-e^{-S}\right)\right]= \\
\left(1+\frac{t-1}{T}+\frac{(t-1)^{2}}{2 \cdot T^{2}}\right) \cdot e^{-\frac{t-1}{T}}-\left(1+\frac{t}{T}+\frac{t^{2}}{2 \cdot T^{2}}\right) \cdot e^{-\frac{t}{T}}, \\
(N=3) .
\end{array}
$$

Assuming that the hyetograph is effective, rainfall can be expressed as

$$
P e(t)=\sum_{i=1}^{M} x_{i} \cdot(\eta(i-1)-\eta(i))(\text { Fig } 4) .
$$

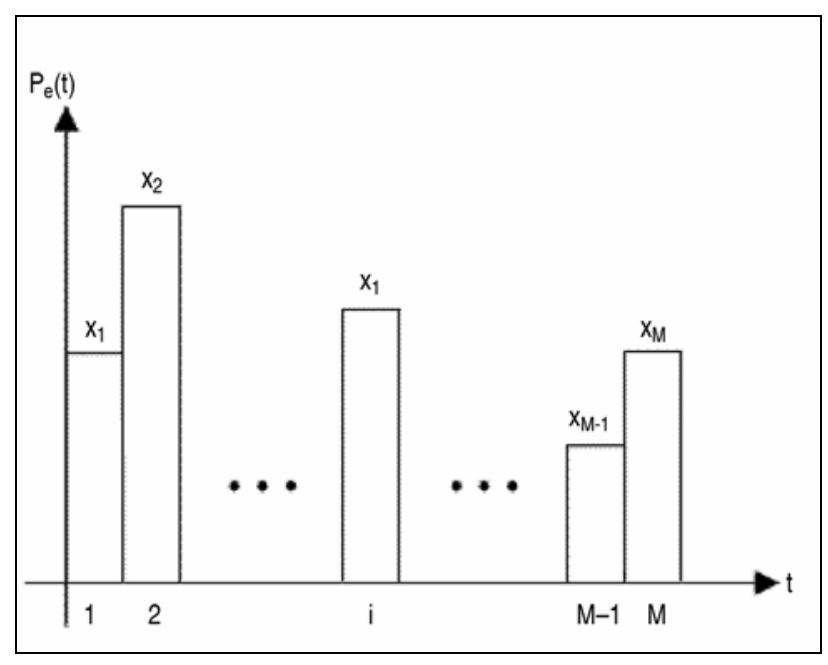

Fig 4. Hyetograph of effective rainfall

Employing both the relationships (12), (13), (14) and the rule of superposition (linear system is considered) simulated values of runoff can be calculated.

For $N=1$ :

$$
H(t=m)=\sum_{i=1}^{m} x_{i} \cdot\left(e^{-\frac{m-i}{T}}-e^{-\frac{m-i+1}{T}}\right),
$$

for $N=2$

$$
H(t=m)=\sum_{i=1}^{m} x_{i} \cdot\left(\left(1+\frac{m-i}{T}\right) e^{-\frac{m-i}{T}}-\left(1+\frac{m-i+1}{T}\right) e^{-\frac{m-i+1}{T}}\right),
$$

for $N=3$

$$
\begin{aligned}
H(t=m)= & \sum_{i=1}^{m} x_{i} \cdot\left(\left(1+\frac{m-i}{T}+\frac{(m-i)^{2}}{2 \cdot T^{2}}\right) e^{-\frac{m-i}{T}}-\right. \\
& \left(1+\frac{m-i+1}{T}+\frac{(m-i+1)^{2}}{2 \cdot T^{2}}\right) e^{\left.-\frac{m-i+1}{T}\right),}
\end{aligned}
$$

where $m=1, \ldots, M ; N, T$ - number of reservoirs, constant moment; $P_{e}$ - effective rainfall; $H$ - runoff. 
The number of reservoirs in the cascade can be estimated as close to 3 for small catchments of the western part of the Polish lowland [15]. The model was originally tested in this region. According to theory, the number of reservoir value belongs to the set of positive real numbers $[13,17]$. However, the model conception illustrated above on the example of a system with 3 reservoirs, the generalized version of modeling with assumption of $\mathrm{N} \in \mathrm{R}+$ was ultimately integrated in dedicated software.

\subsection{Effective rainfall module}

The SCS-CN procedure in its standard form is a well-established modeling method $[18,19,20]$. The standard SCS-CN procedure was developed in the mid of the 20 th century by Soil Conservation Service (a division of the USDA), and since then it has been widely used both as a research tool and for solving practical problems. The method is usually described in textbooks on general and dynamic hydrology [17, 14]. However, a detailed description and profound theoretical analysis of the method has only recently been done [21]. In brief, the SCS-CN model was developed on assumption that the total rainfall is divided into non-runoff components (mainly evapotranspiration and infiltration) and a direct runoff equivalent to effective rainfall. The decisive hydrological processes employed in separation of the total rainfall are, respectively, surface flow and shallow subsurface flow.

The key role in the rainfall separation process could be ascribed to the following physiographic characteristics:

1. Soil characteristics considered as infiltration capability influenced by the current moisture of a soil. The SCS-CN method divides soils into four groups by their infiltration capabilities (hydrologic soil groups);

2. Cover characteristics considered as land use type (land use), applied management practices (treatment or practice) and cover effectiveness (hydrologic condition).

Because of its importance for the investigation described in this paper, the issue of land cover with a particular view on vegetation cover is discussed wider below.

On the basis of empirically identified relationship functioning between the total and effective rainfall, a nondimensional parameter was determined (CN - Curve Number). This parameter combines the properties of land cover with soil properties and is included in the main SCS-CN model equation determining the separation of rainfall. The graphic illustration of the relationship is a set of separation curves. Thus, CN parameter is a function of soil type, soil moisture antecedent to storm rainfall, land cover and land cover management. For an original method, the values of CN parameter are set in tables prepared for the US catchments [20], although an attempt was undertaken to adapt these values to Polish conditions[22].

According to the theory of the SCS-CN method, it is assumed that storm runoff is initiated when the total rainfall $(P)$ (sometimes called maximum potential runoff) exceeds a threshold value called initial abstraction $\left(I_{a}\right)-\mathrm{a}$ certain amount of rainfall permanently excluded from runoff due to initial processes of interception, infiltration and surface retention. The instant of storm runoff initia- tion occurs when actual cumulative infiltration $(F)$ starts to rise and during the storm rainfall its value potentially could reach the limit of potential maximum retention $(S)$ - a distinct value for each catchment in specific physiographic conditions. Simultaneously, effective rainfall $\left(P_{e}\right)$ equal to direct runoff tend to rise together with increase of the total rainfall potentially reaching the limit of the total rainfall lessened by initial abstraction $\left(I_{a}\right)$.

Mathematical description of the SCS-CN model is based on three equations (water balance and two concepts). The water balance equation equates the total rainfall $(P)$ to sum of initial abstraction $\left(I_{a}\right)$, actual infiltration $(F)$ and effective rainfall $(P)$.

The first concept assumes that the ratio of actual infiltration $(F)$ to potential maximum retention $(S)$ equals the ratio of actual effective rainfall (direct runoff) $\left(P_{e}\right)$ to the total rainfall $(P)$ less initial abstraction $\left(I_{a}\right)$.

In addition, the amount of potential maximum retention $(S)$ is related to initial abstraction $\left(I_{a}\right)$ by linear dependence. The measure of the dependence is the coefficient $(\lambda)$.

Thus,

$$
\begin{gathered}
\frac{F}{S}=\frac{P_{e}}{P-I_{a}} . \\
P=I_{a}+F+P_{e} . \\
I_{a}=\lambda \cdot S .
\end{gathered}
$$

In the existing method it is assumed that the value of $\lambda$ coefficient equals 0,2 , although for numerous sites, the empirical value usually $\lambda \in[0 ; 0,3]$ [23].

Thus, usually

$$
I_{a}=0,2 \cdot S
$$

The formula of effective rainfall is derived as a result of transformation of equations (19), (20), (22):

$$
\begin{gathered}
P_{e}=\frac{(P-0,2 \cdot S)^{2}}{P+0,8 \cdot S} ; \text { for } P>I_{a} \\
P_{e}=0 ; \quad \text { for } P \leq I_{a} .
\end{gathered}
$$

For subsequent temporal intervals $i=1,2,3, \ldots, M$ equation (23) is:

$$
P_{e i}=\frac{\left(P_{i}-0,2 \cdot S\right)^{2}}{P_{i}+0,8 \cdot S} .
$$

Potential maximum retention $(S)$ is related to nondimensional parameter $\mathrm{CN} \in[0,100]$

$$
S=25,4 \cdot\left(\frac{1000}{C N}-10\right) .
$$

Although the SCS-CN method was originally intended as universal and was developed on the basis of a wide range of empirical data acquired from sites of various land cover forms, anyway the best results are usually returned in agricultural catchments of a moderate climate zone of North America. More precise modeling for areas of non-agricultural, particularly forest land cover, could not usually be achieved with the existing Standard SCS-CN solution. Thus, successful utilization of the SCS-CN model on forest areas was usually achieved by attempts of various model modifications [24-28]. 


\subsection{Modification of SCS-CN model}

Adopting of the $C N$ parameter values to local cover characteristics on the basis of hydrometeorological data was a key methodological problem to be solved here.

The standard SCS-CN model was initially developed for application in a moderate climatic zone of North America with a rich empirical material as a basis (10 to 20 -yearlong hydrometeorological data series from more than 50 catchments of various land cover). Anyway, in the course of the model development lower amounts of storm rainfall were usually neglected, but the highest values were regarded. Considering numerous catchments with less favorable conditions, the storm runoff is also generated for lower rainfall events. This discrepancy is caused by development of the original SCS-CN method on the basis of the highest storm rainfall series, for the cases of relatively substantial runoff. The key role should be ascribed then to specifics of local physiographic conditions and the pattern of processes governing over runoff in a particular area which impacted the shape of the model. For example, several experimental catchments used for compilation of the method were placed in the area of the US East Coast, where intensive storm events occur with annual precipitation often exceeding $1000 \mathrm{~mm}$ coupled with relatively high evapotranspiration. Although various types of soil and land cover were investigated, long empirical series of data were employed and numerous catchments were tested, the locality of empirical conditions predominantly modulated the final effect [21]. Unfortunately, in many particular implementations, the set of existing $C N$ values usually was not altered but plainly translated without any insight. Universal solution of the above mentioned problem is still a central research issue in successful utilization of the SCS-CN model. The proposition of the problem solution with verification of $C N$ parameter values performed on the example of a Central European lowland forest catchment is described below.

Analysing literature on the subject, it appears that a generalizing verification of the original SCS-CN method with the view of alteration of $C N$ parameter values has not been developed and broadly implemented so far, however, various procedures of a partial model modification were applied [21]. Thus, a great number of model implementations, particularly those in catchments with higher infiltration capabilities of the soil and substantial loss on evapotranspiration, with relatively lower rainfall, need alterations. These unfavorable runoff generation conditions are often present in forest catchments of Polish lowland, in general, in numerous areas of Central European Plain of lower rainfall and high evapotranspiration. The catchment selected for the modified SCS-CN model testing represented these conditions. The procedure of SCS-CN model alteration is described below.

The results of investigation regarding implementation of the SCS-CN method prove that the empirical values of $C N$ parameter (the values returned from relationship between the total rainfall $(\mathrm{P})$ and effective rainfall $\left(P_{e}\right)$ ), in particular catchments, often differ significantly from the values calculated by utilizing the existing original method [29-31]. The problem has also been apparent in numerous local applications of the model worldwide, including implementations on Polish sites.

Regarding the above stated premises of the standard SCS-CN procedure failure, on the basis of empirical data series for selected hydrological year 2001/2002, runoff and corresponding rainfall events were identified and selected. Runoff events genetically related to snowmelt were excluded from farther investigation (snowmelting processes are not considered as cause of runoff in the SCS-CN model). Direct runoff was extracted from the total runoff for the selected events. According to theoretical foundations of the SCS-CN model, direct runoff equals effective rainfall $\left(P_{e}\right)$. The values of the total rainfall $(P)$ were calculated as a sum of daily rainfall for each of the selected events. Thus, for each of the rainfall events, pairs of values were acquired $\left(P_{i}, P_{e i}\right)$. The value pairs are set in Table 1.

Table 1. Empirical values of runoff coefficient $(\alpha)$, total $(P)$ and effective rainfall $\left(P_{e}\right)$ for rainfall events in Trojanka catchment for hydrologic year 2001/2002

\begin{tabular}{|c|c|c|c|c|}
\hline Event period & $\begin{array}{l}\text { Event length } \\
\text { (days) }\end{array}$ & $\begin{array}{c}P \\
(\mathrm{~mm})\end{array}$ & $P_{e}(\mathrm{~mm})$ & $\begin{array}{c}\alpha \\
(-)\end{array}$ \\
\hline 06.11.-08.11.2001 & 3 & 5,1 & 0,017 & 0,003 \\
\hline 21.11.-24.11.2001 & 4 & 11,8 & 0,078 & 0,007 \\
\hline 05.02.-12.02.2002 & 8 & 34,6 & 0,467 & 0,013 \\
\hline 25.02.-26.02.2002 & 2 & 19,2 & 0,138 & 0,007 \\
\hline 13.03.-15.03.2002 & 3 & 19,5 & 0,272 & 0,014 \\
\hline 13.04. -19.04.2002 & 7 & 44,5 & 0,840 & 0,019 \\
\hline 11.05.-14.05.2002 & 4 & 11,3 & 0,086 & 0,008 \\
\hline 25.05 .2002 & 1 & 9,6 & 0,133 & 0,014 \\
\hline 31.05. -01.06.2002 & 2 & 9,8 & 0,035 & 0,004 \\
\hline 06.06. -13.06.2002 & 8 & 20,4 & 0,190 & 0,009 \\
\hline 27.06. -04.07 .2002 & 8 & 13,0 & 0,044 & 0,003 \\
\hline 22.07. -24.07.2002 & 3 & 17,1 & 0,147 & 0,009 \\
\hline $04.08 .-05.08 .2002$ & 2 & 25,1 & 0,279 & 0,011 \\
\hline 10.08. -15.08.2002 & 6 & 38,4 & 0,368 & 0,010 \\
\hline 14.09. -15.09 .2002 & 2 & 15,6 & 0,195 & 0,013 \\
\hline $04.10 .-08.10 .2002$ & 5 & 32,2 & 0,644 & 0,020 \\
\hline 12.10. -15.10 .2002 & 4 & 11,6 & 0,064 & 0,006 \\
\hline 21.10. -30.10 .2002 & 10 & 49,5 & 1,014 & 0,020 \\
\hline
\end{tabular}

The following equation is derived from transformed equation (23):

$$
S_{i}=5 \cdot\left(P_{i}+2 \cdot P e_{i}-\sqrt{4 \cdot P e_{i}^{2}+5 \cdot P_{i} \cdot P e_{i}}\right),
$$

where $S_{i}$ - empirical potential maximum retention corresponding with pair of values $\left(P_{i}, P_{e i}\right), P_{i}$-total rainfall for $\boldsymbol{i}$ runoff event, $P_{e i}-$ effective rainfall for $\boldsymbol{i}$ runoff event.

Equation (27) was used for calculation of potential maximum retention $\left(S_{i}\right)$ for each pair of $\left(P_{i}, P e_{i}\right)$ values, respectively for each rainfall event resulting in runoff in the investigated catchment for hydrological year 2001/2002. Then, after transformation of equation (26) for an average empirical value of potential maximum retention $\left(S_{\mathrm{emp}}\right)$ a corresponding value of $C N$ parameter was calculated $\left(C N_{\text {emp }}\right)$ for the tested catchment in hydrological year 2001/2002 [29]:

$$
C N_{\text {emp }}=\frac{25400}{254+S_{\text {emp }}},
$$


where $C N_{\text {emp }}$ - average empirical value of $C N$ parameter, $S_{\text {emp }}$ - average empirical value of potential maximum retention.

On the basis of theoretical foundation of the SCS-CN method it can be assumed that the boundary values of SCS-CN parameter, respectively $C N=1$ and $C N=100$, are constant in any catchment (under any physiographic conditions). Namely, for $C N=1$, effective rainfall (direct runoff) should not occur regardless of the level of storm rainfall (e g rainfall on an absolutely permeable surface), otherwise, for $C N=100$, the total storm rainfall volume is transformed into direct runoff (e g rainfall on a water surface or an absolutely impermeable surface).

Taking the above assumption of equality of lower and upper boundary values of $C N$ parameter and, in addition, considering the values of $C N$ parameter calculated of empirical data series for the investigated catchment, the pairs of $C N$ parameter values could be set. Values of the pairs are, respectively, the $C N$ values calculated by a standard procedure and the $C N$ values calculated by an altered procedure (by equation 28) with utilization of empirical data matching local physiographic conditions of the catchment.

Table 2. Empirical values of $C N$ parameter according to modified method for Trojanka catchment (average moisture conditions AMCII)

\begin{tabular}{|c|c|c|c|c|c|}
\hline \multirow{2}{*}{ Land use } & \multirow{2}{*}{ Degree of density } & \multicolumn{4}{|c|}{ Soil group } \\
\hline & & $\mathrm{A}$ & $\mathrm{B}$ & $\mathrm{C}$ & $\mathrm{D}$ \\
\hline \multirow{10}{*}{ Forest stand } & 0,1 & 72,1 & 88,5 & 93,9 & 96,1 \\
\hline & 0,2 & 70,0 & 87,9 & 93,4 & 95,7 \\
\hline & 0,3 & 67,8 & 86,7 & 93,0 & 95,4 \\
\hline & 0,4 & 64,3 & 86,1 & 92,6 & 95,0 \\
\hline & 0,5 & 61,8 & 84,7 & 92,1 & 94,7 \\
\hline & 0,6 & 60,4 & 84,1 & 91,6 & 94,7 \\
\hline & 0,7 & 59,1 & 83,4 & 91,6 & 94,3 \\
\hline & 0,8 & 56,3 & 82,6 & 91,2 & 94,3 \\
\hline & 0,9 & 54,9 & 81,9 & 91,2 & 93,9 \\
\hline & $\geq 1$ & 53,4 & 81,1 & 90,6 & 93,9 \\
\hline \multicolumn{2}{|c|}{ Forest planting of less than 3 years } & 78,7 & 90,6 & 95,4 & 97,0 \\
\hline \multicolumn{2}{|c|}{ Forest planting of more than 3 years } & 73,1 & 88,5 & 93,9 & 96,1 \\
\hline \multicolumn{2}{|c|}{ Failplace of less than 3 years } & 75,1 & 89,6 & 94,7 & 96,4 \\
\hline \multicolumn{2}{|c|}{ Failplace of more than 3 years } & 68,9 & 87,3 & 93,0 & 95,4 \\
\hline \multirow{3}{*}{$\begin{array}{l}\text { Burned forest area } \\
\text { (high burn) }\end{array}$} & $0,1-0,3$ & 72,1 & 88,5 & \begin{tabular}{|l|}
93,9 \\
\end{tabular} & 96,1 \\
\hline & $0,4-0,6$ & 64,3 & 86,7 & 92,6 & 95,0 \\
\hline & $\geq 0,7$ & 59,1 & 83,4 & 91,6 & 94,3 \\
\hline \multicolumn{2}{|l|}{ Industrial swards } & 77,8 & 91,2 & 95,4 & 96,7 \\
\hline \multicolumn{2}{|l|}{ Industrial shrubs } & 70,0 & 87,9 & 93,4 & 95,7 \\
\hline \multicolumn{2}{|l|}{ Grassy fallows } & 76,9 & 90,6 & 90,6 & 96,4 \\
\hline \multicolumn{2}{|c|}{ Row crops (historical condition) } & 91,6 & 95,4 & 97,6 & 98,4 \\
\hline \multicolumn{2}{|c|}{ Row crops (contemporary condition) } & 89,1 & 94,3 & 96,7 & 97,9 \\
\hline \multicolumn{2}{|c|}{ Small grain crops (historical condition) } & 87,9 & 93,4 & 96,4 & 97,6 \\
\hline \multicolumn{2}{|c|}{ Small grain crops (contemporary condition) } & 86,7 & 93,0 & 96,1 & 97,3 \\
\hline \multicolumn{2}{|l|}{ Pastures } & 76,0 & 90,1 & 94,7 & 96,4 \\
\hline \multicolumn{2}{|l|}{ Rural settlements } & 84,1 & 92,6 & 95,7 & 97,0 \\
\hline \multicolumn{2}{|l|}{ Swamp } & \multicolumn{4}{|c|}{99,8} \\
\hline \multicolumn{2}{|l|}{ Water bodies } & \multicolumn{4}{|c|}{100} \\
\hline
\end{tabular}

Subsequently, the generalized form of an empirical equation developed for derivation of the $C N$ parameter values (the values corresponding with the conditions of a particular catchment) from the standard method $C N$ values was employed [32]:

$$
C N_{e}=\frac{100}{a \times\left(\frac{100}{C N}-1\right)^{b}+1},
$$

where $C N_{e}$ - empirical value of the $C N$ parameter; $C N$ value of the $C N$ parameter calculated by standard method: $a, b$-empirical coefficients of the method.

The values of coefficients $(a, b)$ which respectively equal $a=30$ and $b=1,26$ were calculated from regression equation (29). Empirical values of $C N$ parameters were calculated from corresponding existing standard method values of the $C N$ parameter on the basis of parameterized equation (29). The empirical values of $C N$ parameter for conditions of the tested catchment are set in Table 2.

\section{Results and discussion}

The model was tested in Trojanka Stream catchment (the gauged area of $22,78 \mathrm{~km}^{2}$ ), located in the western part of Polish lowland (the Oder river basin). As for universal classification of physiographic regions the catchment area belongs to Gniezno Lakeland macroregion (315.54). The closing gauging section was located $18 \mathrm{~km}$ NE from the city of Poznan (geographical coordinates of outfall $52^{\circ} 35^{\prime} 03^{\prime}$ 'N $17^{\circ} 04^{\prime} 50^{\prime}$ 'E). The leading factors modulating non-climatic, non-vegetation physiograhic conditions in the catchment were glacial and fluvioglacial processes of Würm glaciation. The distinctive features of land cover of Trojanka catchment are dynamic processes of land use changes. The processes of both afforestation coupled with reduction of agricultural land cover, shape the framework of land use changes in the course of the last 200 years. The climate of the catchment region is transitional (thermal patterns tend to be more oceanic, but precipitation tend to be more continental). Average annual precipitation is $575 \mathrm{~mm}$, average annual temperature is $8,0^{\circ} \mathrm{C}$. Selected physiographic parameters and characteristics of Trojanka Stream and its catchment are set in Table 3.

Farther investigations were carried out on assumption that changes of land cover in the investigated catchment are caused by non-climatic factors. Climate changes directly affect hydrologic regimes, including changes of rainfall-runoff process pattern. Furthermore, the issue of event probability for defined cover cases and a more thorough analysis of processes related to their development are also placed beyond the scope of the described herein investigation.

Land cover cases were defined with the view to quantitative and/or qualitative vegetation properties and their changes. Respectively, forest vegetation and/or nonforest vegetation changes may occur. Through these changes a new cover states would settle and establish as an expression of a temporal equilibrium state.

Thus, detailing of the $C N$ parameter values was employed. The detailing was performed according to diversity of land cover forms located in the tested catchment, with a thorough view to distinction of local forest vegetation and its predicted potential changes. The foundation for the detailing included the theoretical basis of the SCS-CN method, the solutions applied in a few implementations of the method on areas of a similar land cover - both forest and non-forest - and above all the implementations which included working solutions in generalizing of detailing cover forms [33]. 
Altogether, 11 cases of land cover state, which affect runoff from the catchment, were specified. The cover state cases included: current state conditions, reconstructed conditions of historic cover state, the other 9 cases were defined as a result of hypothetical influence of selected natural processes or/and land management effects. Land cover cases are concisely described below, although a broad description may be found in [33].

Table 3. Selected physico-geographical parameters of Trojanka catchment

\begin{tabular}{|c|c|c|}
\hline Physico-geographical characteristics & \multicolumn{2}{|c|}{ Value } \\
\hline Land cover & {$\left[\mathrm{km}^{2}\right]$} & {$[\%]$} \\
\hline Forest & 20,20 & 88,7 \\
\hline Arable & 0,65 & 2,8 \\
\hline Meadow and pasture & 0,65 & 2,8 \\
\hline Fallow and wasteland & 0,57 & 2,5 \\
\hline Swamp, lake and pond & 0,48 & 2,2 \\
\hline Settlements & 0,23 & 1,0 \\
\hline Soil cover & \multicolumn{2}{|c|}{$N^{2}$} \\
\hline Sandy soil & 22,05 & 96,8 \\
\hline Clayey soil & 0,39 & 1,7 \\
\hline Peaty and mucky soil & 0,34 & 1,5 \\
\hline Relief form & \multicolumn{2}{|c|}{${ }^{2}$} \\
\hline Morainic and sandr plateau & 18,88 & 82,9 \\
\hline River valley (bottom and the slopes) & 3,90 & 17,1 \\
\hline Geometric characteristics & \multicolumn{2}{|c|}{3} \\
\hline Total area $\left[\mathrm{km}^{2}\right]$ & \multicolumn{2}{|c|}{22,78} \\
\hline Catchment length [km] & \multicolumn{2}{|c|}{7,83} \\
\hline Mean catchment width [km] & \multicolumn{2}{|c|}{2,91} \\
\hline Catchment perimeter length [km] & \multicolumn{2}{|c|}{27,90} \\
\hline Catchment compactness ratio $[-]$ & \multicolumn{2}{|c|}{1,65} \\
\hline Relief & \multirow{2}{*}{\multicolumn{2}{|c|}{$\sum{ }_{1188}$}} \\
\hline Maximum elevation catchment point [m] asl & & \\
\hline Minimum elevation catchment point $[\mathrm{m}]$ asl & \multicolumn{2}{|c|}{$\begin{array}{c}118,8 \\
73,7\end{array}$} \\
\hline Denivelation [m] & \multicolumn{2}{|c|}{45,1} \\
\hline Mean catchment elevation [m] asl & \multicolumn{2}{|c|}{96,3} \\
\hline Mean catchment slope [\%o] & \multicolumn{2}{|c|}{9,4} \\
\hline Mean stream axis catchment slope [\%o] & \multicolumn{2}{|c|}{2,7} \\
\hline Mean valley axis catchment slope [\%o] & \multicolumn{2}{|c|}{22,7} \\
\hline Hydrological and hydrographical parameters & \multicolumn{2}{|c|}{$\mathrm{S}$} \\
\hline Mean specific discharge $\left[\mathrm{dm}^{3} \cdot \mathrm{s}^{-1} \cdot \mathrm{km}^{2}\right]$ & \multicolumn{2}{|c|}{2,5} \\
\hline Length of main stream $[\mathrm{km}]$ & \multicolumn{2}{|c|}{7,49} \\
\hline Total length of hydrographical network [km] & \multicolumn{2}{|c|}{8,44} \\
\hline Mean hydrographical network density $\left[\mathrm{km} / \mathrm{km}^{2}\right]$ & \multicolumn{2}{|c|}{0,37} \\
\hline Mean main stream slope [\%o] & \multicolumn{2}{|c|}{2,2} \\
\hline Maximum/ minimum main stream slope [\%o] & \multicolumn{2}{|c|}{$0,3 / 17,9$} \\
\hline
\end{tabular}

Current conditions

Current state conditions were defined according to land cover state characteristics of 2002. century)

Reconstructed historic conditions (turn of the 19 th

According to historical records, estimated proportion of land use categories for historic conditions is: forests $69,0 \%$, arable $-20,5 \%$, pastures $-8,0 \%$. Forest management practices non conforming with modern principles of sustained yield and rules of silviculture were employed (selective destructive logging, grazing and forest litter removing, natural or semi-natural forest regeneration, partial employment of the coppice system). As a result, mixed with a large proportion of oak, unevenaged, sparsely closed and badly shaped stands prevailed. Coppice, brush wood and bare land areas were relatively common. Thus, following distribution of forest stand density was proposed 0,3 for $5 \%$ forest area $(0,3$ stands for $30 \%$ density). The other values were respectively: $(0,4 ; 15 \%) ;(0,5,15 \%) ;(0,6,15 \%) ;(0,7,15 \%) ;(0,8$,
$10 \%) ;(0,9,10 \%)$, and 1,0 density at $5 \%$ of forest area. The settlement network was better developed in comparison with contemporary state. Rural economy was supported by corn production (mainly rye ca $70 \%$ of arable land) and root crops (introduction of potatoes). Animal production was carried out mainly on forest and pasture (grazing pig, cattle and substantial proportion of sheep prevailed).

\section{Total deforestation}

Cover state of absolute catchment deforestation was defined as a result of hypothetical area environmental catastrophe. This event of forest ecosystem destruction may occur as an effect of synergic interaction of various factors, such as environmental pollution, tree pathogens, insect gradation, periods of unfavorable meteorological conditions. Then the substitutional vegetation communities would develop as a replacement. Proposed substitutional vegetation was a combination of brushwood and herbaceous cover in three proportion variants: (1) 40, $60 \%$; (2) $0 \%$ and $100 \%$ or (3) $100 \%$ and $0 \%$. The swamp areas would exist in the catchment in current state extent, but settlements and agricultural land use would not occur.

\section{Total afforestation}

Total afforestation cover state case was developed on assumption that the only form of vegetation at the locations of potential forest vegetation sites are forests. The character of forest in currently deforested areas would be similar to contemporary condition of forests (as in 2002). Natural non-forest vegetation (water and swamp communities) would stay unaltered.

Partial deforestation (transformation of the most fertile areas in arable land)

Transformation of woodland into arable land was assumed for the most fertile parts of the catchments (selection of larger coherent areas of fresh mixed broadleaved forest site located on upland with favorable for ploughing relief conditions). Land use for other areas would be the same as in 2002. Transformed land (ca 300 ha) would be cultivated with root crop (e g potatoes).

\section{Partial forest burn}

Forest burn would occur on $(355,44$ ha). The rest of cover would stay the same as in 2002 . Two variants were considered for forest burn case: (1) immediately after the burn; (2) after regeneration by planting on the burned forest area (3-year-old new growth).

\section{Decrease of forest stand health (die back of trees)}

Decrease of forest stand health may occur due to conditions similar as for the total deforestation of the considered area. As a result of these conditions, disintegration of forest ecosystem may follow, including processes of tree dying back, braking stand density. Two variants were specified for the case: reduction by half of: (1) pine proportion, (2) oak proportion. The trees no younger than 50 years and dominant species composing at least $70 \%$ of tree composition in stands were considered. Initial stand condition would be the same as in 2002. 
The values of $C N$ parameters for each cover state case were calculated (by means of dedicated software) as a weighted average value (the weighting factor was the area corresponding with each recognized homogeneous plot differing by the $C N$ value) e g for forest areas, these homogeneous plots were the lowest level forest inventory units. The values of $C N$ parameter for land cover state cases are set in Table 4.

$$
C N_{s}=\frac{1}{A} \sum_{i=1}^{n} C N_{i} \Delta A_{i}, \quad A=\sum_{i=1}^{n} \Delta A_{i},
$$

where $C N_{s}$ - average value of $C N$ parameter in the catchment; $C N_{i}$ - value of $C N$ parameter for each homogeneous unit in the catchment $\left(\triangle A_{i}\right) ; A-$ total area of the catchment; $\Delta A_{i}$ - area of each homogeneous unit; $n-$ number of homogeneous units.

Table 4. Values of $C N$ parameters for specified land cover state cases of Trojanka catchment

\begin{tabular}{c|l|c}
\hline No & Land cover state case & $\begin{array}{c}C N_{s} \\
(-)\end{array}$ \\
\hline 1 & Current state conditions & 72,2 \\
\hline 2 & Historical conditions (turn of the 18th/19th c) & 80,6 \\
\hline 3 & Total deforestation (40\% swards, 60\% shrubs) & 82,0 \\
\hline 4 & Total deforestation (60\% swards, 40\% shrubs) & 79,9 \\
\hline 5 & Total deforestation (100\% swards) & 85,2 \\
\hline 6 & Total afforestation & 71,2 \\
\hline 7 & $\begin{array}{l}\text { Partial deforestation (transformation of fertile areas } \\
\text { in to arable land) }\end{array}$ & 74,6 \\
\hline 8 & Partial forest burn (immediately after burn) & 72,5 \\
\hline 9 & $\begin{array}{l}\text { Partial forest burn (3-year-old new growth on burned } \\
\text { area) }\end{array}$ & 74,2 \\
\hline 10 & $\begin{array}{l}\text { Decrease of forest stand health (partial die back of } \\
50 \text {-year-old Scots pine stands) }\end{array}$ & 73,9 \\
\hline 11 & $\begin{array}{l}\text { Decrease of forest stand health (partial die back of } \\
50 \text {-year-old common oak stands) }\end{array}$ & 72,7 \\
\hline
\end{tabular}

The rainfall events selected for model adaptation procedure occurred in vegetation period with homogenous antecedent moisture conditions within AMCII class according to the existing SCS-CN method. Thus, the modified method may only be applied for similar antecedent moisture conditions, namely, AMCII.

Testing of the altered model was performed on the example of rainfall events occurring in vegetation period. The results of modeling were illustrated on two rainfall events, differing in distribution of rainfall over time, one of which is cumulated 04.08-05.08.2002 $P=25,1 \mathrm{~mm}$, and the other distributed 04.10-08.10.2002 $P=32,2 \mathrm{~mm}$ (Table 5).

The mean error of effective rainfall approximation, respectively, at 93 and $44 \%$ may be assessed as acceptable.

The cases of specified land cover state would settle as a result of hypothetical processes transforming quantitative or/and qualitative characteristics of cover. Comparative measure evaluating the impact of these changes on direct runoff, both the direction and extent, is the index designed as a ratio of runoff coefficients, respectively for a given case of land cover state and for the state of maximum runoff coefficient (the state of total deforestation of the catchment with herbaceous cover present case 5):

$$
c=\frac{\alpha_{i}}{\alpha_{\max }} \cdot 100(\%),
$$

where $c$ - index of direct runoff $(\%) ; \alpha_{i}$ - runoff coefficient for $i$ land cover case (-); $\alpha_{\max }-$ maximum value of direct runoff coefficient (-).

Table 5. Simulated values of effective rainfall for specified land cover cases of Trojanka catchment and selected (empirical) rainfall events

\begin{tabular}{c|c|c|c|c|c}
\hline \multirow{2}{*}{$\begin{array}{c}\text { Land } \\
\text { cover state } \\
\text { cases }\end{array}$} & \multirow{2}{*}{$\begin{array}{c}C N \\
(-)\end{array}$} & $\begin{array}{c}\text { Effective } \\
\text { rainfall }\end{array}$ & $\begin{array}{c}\text { Runoff } \\
\text { coefficient }\end{array}$ & $\begin{array}{c}\text { Effective } \\
\text { rainfall }\end{array}$ & $\begin{array}{c}\text { Runoff } \\
\text { coefficient }\end{array}$ \\
\cline { 3 - 6 } & & \multicolumn{2}{|c}{$P=25,1$} & \multicolumn{2}{c}{$P=32,2$} \\
\hline 1 & 72,2 & 0,28 & 0,011 & 1,45 & 0,045 \\
\hline 2 & 80,6 & 2,24 & 0,089 & 4,92 & 0,153 \\
\hline 3 & 82 & 2,79 & 0,111 & 5,77 & 0,179 \\
\hline 4 & 79,9 & 1,99 & 0,079 & 4,53 & 0,141 \\
\hline 5 & 85,2 & 4,39 & 0,175 & 8,1 & 0,252 \\
\hline 6 & 71,2 & 0,19 & 0,008 & 1,19 & 0,037 \\
\hline 7 & 74,6 & 0,65 & 0,026 & 2,19 & 0,068 \\
\hline 8 & 72,5 & 0,33 & 0,013 & 1,53 & 0,048 \\
\hline 9 & 74,2 & 0,58 & 0,023 & 2,05 & 0,064 \\
\hline 10 & 73,9 & 0,53 & 0,021 & 1,96 & 0,061 \\
\hline 11 & 72,7 & 0,36 & 0,014 & 1,59 & 0,049 \\
\hline
\end{tabular}

The values of direct runoff index for the cases of specified land cover state are set in Fig 5.

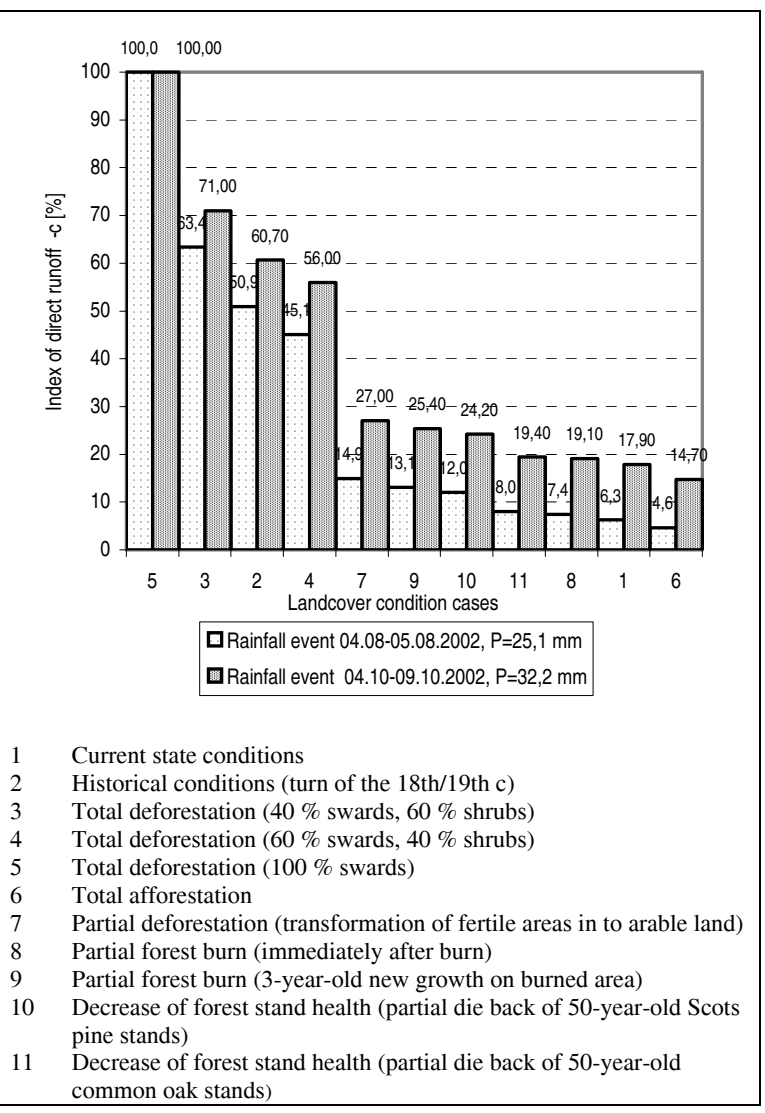

Fig 5. Index of direct runoff of Trojanka catchment for specified land cover cases 
Relatively the least favorable conditions for direct runoff generation would occur for the case of total afforestation of Trojanka catchment (land cover case 6). Forest cover proportion currently at nearly $90 \%$ (land cover state 1) supports already substantial reduction of runoff potential, thus in comparison with current state the reduction of runoff measured by direct runoff index is relatively low (less than $5 \%$ ). On the other hand, comparing direct runoff potential of total afforestation case with the case of total deforestation (land cover case 5 - herbaceous swards composing $100 \%$ of catchment cover), the rate of direct runoff index for these cases is as ca 1 to 10.

Some land cover state cases were specified as settled due to qualitative changes of land cover characteristics, namely, reduction of common oak and Scots pine in forest stands (land cover state cases 10 for Scots pine, and 11 - for common oak) or cases settled as a result of forest destruction and subsequent regeneration on $17,6 \%$ area (initial period of forest regeneration - case 9).

The values of direct runoff indexes for the above mentioned cases differed in comparison with current land cover state case by no more than $10 \%$. Thus, a conclusion stating that forest vegetation quality changes, taking place with preservation of forest cover proportion, modulate direct runoff potential to a lower extent is quite justified. The above stated notion might gain even a firmer support considering the fact that some of these qualitative changes would affect quite a substantial share of the total catchment area (e $\mathrm{g}$ for Scots pine reduction case the area is $21,1 \%$ of the total catchment area).

As far as direct runoff potential is concerned, the cases, for which only the changes of qualitative vegetation characteristics were specified, are in opposition to the cases for which land use form would get transformed from forest to non-forest. Apparent increase of runoff potential is noticed for these cases where the catchment would get voided of forest vegetation. Although the most favorable runoff generation conditions would occur for a total deforestation case (land cover case 5), nevertheless, substantial increase of runoff may occur for other non-forest vegetation cases with partial brushwood cover (cases 3 and 4, the index of direct runoff would rise up to $50 \%$ ). Likewise, for reconstructed historic land cover state of the strongest recorded deforestation of Trojanka catchment and historic pattern of land management (case 2), the increase of direct runoff potential would reach a similar level (ca 60-70\%) as for the cases of total deforestation of the test catchment.

On the other hand, partial reduction of the forest cover area, regardless if related to transformation of forests into arable land (case 7) or destruction of forests because of fire (case 8) would result in apparent increase of direct runoff potential, specifically reduction of forest area by ca $15 \%$ resulted in increase of direct runoff by nearly $10 \%$.

Finally, it should be stated here that due to relatively short empirical hydrometeorological data series utilized for calibration of the $C N$ parameter (the data were collected for one hydrological year), the results of modeling presented above may be considered as a kind of ranking showing general trends of direct runoff changes caused by land cover transformation, leaving the quatitive aspect of modeling as a broad approximation. However, the shortage of empirical hydrometeorological data employed for the $C N$ parameter values calibration can be regarded, in general, as an advantage in certain cases. It still allows quick approximation of direct runoff. More precise results of modeling could be achieved only through calibration on the basis of longer data series.

Another issue related to the SCS-CN model implementation accuracy is the problem of $\lambda$ value (formula 21 ). It is usually assumed that $\lambda$ value is 0,2 (assumption employed for the purpose of described herein $C N$ parameter value calibration). However, it should be admitted that the empirical values of $\lambda$ coefficient vary for different catchments, usually from 0 to 0,3 , and might be approximated through various procedures of calibration founded on relatively long empirical data series. Similarly, different antecedent moisture content (AMC) could be taken into account while calibrating the $C N$ parameter empirical values if longer data series were available with more varied rainfall event conditions.

\section{Conclusions}

\section{General model assessment}

1. Utilization of the SCS-CN model in the existing standard form could not rather be recommended in typical physiographic conditions of large sections of Central European lowland.

2. The SCS-CN model adaptation on the basis of the $C N$ parameter calibration procedure with utilization of long series of empirical data may result in removing of the standard method limitation for the area of Central European lowland.

3. Prospects of reliable utilization of the SCS-CN model in the future depends on fulfilling the following requirements:

a) regionalization and detailing of the $C N$ parameter sets for various land cover types, (nonforest included), in larger, relatively homogeneous spatial units;

b) determination of model application limitations, related both to the model concept and regional physiographic conditions.

Direct runoff conditions as influenced by land cover changes in the tested catchment

4. Current cover state (forest of nearly $90 \%$ ) causes significant reduction of direct runoff potential from the catchment. Further afforestation (potentially up to $97 \%$ ) would result only in a low additional reduction of direct runoff (by less than $5 \%$ ).

5. Changes of the forest environment quality (dying back of main forest tree species) would cause a relatively lower hydrological effect manifested by increase of direct runoff in comparison with changes of the forest cover proportion in the catchment.

6. The highest increase of direct runoff would occur for the case of land cover transformation. The increase of runoff could already be observed if the forest area is reduced by ca $15 \%$ (e g forest burn or transformation of forests into arable land). 
7. Total deforestation of the catchment could increase direct runoff from the area approximately tenfold.

8. Hydrological effect for the historic cover case of the highest recorded deforestation could be compared to the effect of non-forest land cover existence in the catchment (bushes and herbaceous swards).

\section{References}

1. SULIŃSKI, J. Czynniki różnicując wartości składowych bilansu wodnego drzewostanów zagospodarowanych zrębowo. Sylwan, 11, Warszawa, 1995, p 49-65.

2. ANDREASSIAN, V. Waters and forests: from historical controversy to scientific debate. Journal of Hydrology, 291, 2004, p 1-27.

3. SULIŃSKI, J. Podstawowe założenia w nauczaniu hydrologii leśnej. Sylwan, 12, Warszawa, 2002, p 69-79.

4. SWANK, W. T.; MEYER, J. L.; CROSSLEY, D. A. Jr. Long-term ecological research: Coweeta history and perspectives. In Holistic Science: The Evolution of the Georgia Institute of Ecology (1940-2000). Chapter 8, Sheridan Books, Ann Arbor, 2001, p 143-163.

5. MCDONNELL, J. J.; WOODS, R. On the need for catchment classification. Journal of Hydrology, 2004, 299, p 2-3.

6. SEIBERT, J. Conceptual runoff models fiction or representation of reality? Compr. Summ. of Uppsala Dissertations from the Faculty of Science and Technology, 436, Acta Universitatis Uppsaliensis, Uppsala, 1999.

7. LORUP, J. K.; REFSGAARD, J. C.; MAZVIMAVI, D. Assessing the effect of land use change on catchment runoff by combined use of statistical tests and hydrological modeling: case studies from Zimbabwe. Journal of $\mathrm{Hy}$ drology, 1998, 205, p 147-163.

8. BRAUD, I.; VICH, A.; ZULUAGA, J.; FORNERO, L.; PEDRANI, A. Vegetation influence on runoff and sediment yield in the Andes region: observation and modeling. Journal of Hydrology, 2001, 114, p 124-144.

9. HUNDECHA, Y.; BARDOSSY, A. Modeling of the effect of land use changes on the runoff generation of a river basin through parameter regionalization of a watershed model. Journal of Hydrology, 2004, 292, p 281-295.

10. CAMORANI, G.; CASTELLARIN, A.; BRATH, A. Effects of land-use changes on the hydrologic response of reclamation systems. Physics and Chemistry of the Earth, 2005, 30, p 561-574.

11. CHANG, M. Forest Hydrology. CRC Press, Washington, 2003.

12. Global Forest Recourses Assessment. Progress towards sustainable forest management. UN FAO, ID, Rome, 2006.

13. NASH, J. E. Determining runoff from rainfall. In Proc. of Institution of Civil Engineers, 1958, 10, p 163-184.

14. BEAVEN, K. J. Rainfall-runoff modeling. The primer. Wiely, Chichester, 2001.

15. MILER, A. Wymiar fraktalny sieci rzecznych w małych zlewniach Wielkopolski. Rocz. AR Pozn., 268, Melior. Inż. Środ., 15, 1, Poznań, 1994, p 255-266.

16. MILER, A. Podstawy automatyki. Wyd. AR, Poznań, 1981.

17. CHOW, V. T.; MAIDMENT, D. R.; MAYS, L. W. Applied Hydrology. McGraw-Hill Book Company, New York, 1988.
18. USDA-SCS. National Engineering Handbook. Hydrology. Section 4, US Dept. of Agriculture, National Resources Conservation Service, Washington D.C., 1956.

19. USDA-SCS. National Engineering Handbook. Hydrology. Section 4, US Dept. of Agriculture, National Resources Conservation Service, Washington D.C., 1972.

20. USDA-NRCS. National Engineering Handbook. Hydrology. Section 4, US Dept. of Agriculture, National Resources Conservation Service, Washington D.C., 1985.

21. MISHRA, S. K.; SINGH, V. P. Soil Conservation Service Curve Number (SCS-CN) Methodology. Kluwer Academic Publishers, Dordrecht, $2003 \mathrm{~b}$.

22. IGNAR, S. Metodyka obliczania przeptywów wezbraniowych $w$ zlewniach nieobserwowanych, Wyd. SGGW, Rozpr. Nauk. i Monogr., Warszawa, 1993.

23. MISHRA, S. K.; SINGH, V. P. SCS-CN Method. Part I: Derivation of SCS-CN-Based Models. Acta Geophysica Polonica, 2002, Vol 50, No 3, p 457-477.

24. HJELMFELT, A. T. Curve number procedure as infiltration method. Journal of the Hydraulics Division, 1980, 106 (HY6), p 1471-1476.

25. MADRAMOOTOO, C. A.; ENRIGHT, P. Applicability of the Soil Conservation Service equations for runoff prediction in the Ottawa St.Lawrence Lowlands. Canadian Journal of Civil Engineering, 1987, Vol 15, p 759-765.

26. CORBETT, C. W.; WAHL, M.; PORTER, E. P.; EDWARDS, D.; MOISE, C. Nonpoint source runoff modeling. A comparison of a forested watershed and an urband watershed on the South Carolina coast. Journal of Experimental Marine Biology and Ecology, 1997, 213, p 133-149.

27. JOHNSON, R. R. An Investigation of Curve Number Applicability to Watersheds in Excess of 25000 Hectares $\left(250 \mathrm{~km}^{2}\right)$. Journal of Environmental Hydrology, 1998, Vol 6, 5, p 1-10.

28. LYON, S. W.; WALTER, T.; MARCHANT, P. G.; STEENHUIS, T. S. Using a topographic index to distribute variable source area runoff predicted with the SCS Curve Number equation. Hydrol. Processes, 2004, 18, p 2757-2771.

29. HAWKINS, R. H. Runoff curve numbers from partial area watersheds. In Proc. American Society of Civil Engineering, 1979, 105(IR4), p 375-369.

30. HJELMFELT, A. T.; WOODWARD, D. A.; CONAWAY, G.; PLUMMER, A.; QUAN, Q. D.; VAN MULLEM, J. A.; HAWKINS, R. H.; RIETZ, D. Curve Numbers, Recent Developments. In International Association of Hydraulic Engineering and Research (IAHR), 16-21 September. Congress Proceedings, Beijing, 2001, p 1-13.

31. MISHRA, S. K.; SINGH, V. P. SCS-CN Method. Part II: Analytical Treatment. Acta Geophysica Polonica, 2003a, Vol 51, No 1, p 107-123.

32. WOODWARD, D. E.; HAWKINS, R. H.; JIANG, R.; HJELMFELT, A. T.; VAN MULLEM, J. A.; QUAN, D. Q. Runoff Curve Number Method: Examination of the Initial Abstraction Ratio In A.S.C.E./E.W.R.I. World Water and Environmental Resources Congress, 24-26 Jun 2003. Proceedings, Philadelphia, 2003.

33. OKOŃSKI, B. Aktualny stan stosunków wodnych $w$ Puszczy Zielonka $i$ kierunki przewidywanych zmian. Maszyn. KIL. AR, Poznań, 2004. 


\section{ŽEMĖS PANAUDOS KAITOS ITTAKA HIDROLOGINIAMS PROCESAMS EUROPOS LYGUMOS MIŠKŲ BASEINUOSE}

\section{B. Okoński}

\section{Santrauka}

Miško aplinką apibūdinančios savybės, ypač miškų augalija ir miškų dirvožemis, yra pagrindinès ne klimatinės priežastys, turinčios įtakos hidrologiniams procesams miškų ekosistemose. Buvo tirta žemès panaudos kaitos itaka tiesioginiam nuotėkiui miškų baseinuose ir tam buvo taikytas hidrologinis modeliavimas. Nuotėkio modelis buvo suformuotas kaip linijinių rezervuarų kaskada. Kritulių atskyrimo modelis paremtas SCS-CN metodu, šiek tiek pakeistu remiantis unikalia metodika. Taigi daugiausia pastangų buvo skirta metodiniam sprendiniui gauti. Modelis buvo patikrintas žemumų miško baseine, plytinčiame Centrinès Europos lygumos Lenkijos dalyje. Jis buvo kalibruojamas, atsižvelgiant i̇ dabartinę žemès dangos būklę remiantis 9 spejjamais atvejais ir tokiu atveju, jei būtų atkurta istorinè žemès danga. Žemès dangos būklè buvo aprašoma remiantis kiekybiniais ar (arba) kokybiniais augalijos savybių pakitimais.

Reikšminiai žodžiai: lietaus nuotèkio modeliavimas, tiesioginis nuotėkis, $S C S$ - $C N$ metodas, miško baseinas, žemės dangos kaita.

\section{ВЛИЯНИЕ ИЗМЕНЕНИЯ ПОЛЬЗОВАНИЯ ЗЕМЛЕЙ НА ГИДРОЛОГИЧЕСКИЕ ПРОЦЕССЫ В ЛЕСНЫХ БАССЕЙНАХ ЕВРОПЕЙСКОЙ РАВНИНЫ}

\section{Б. Оконский}

Резюме

Окружающую среду леса характеризуют лесные растения и лесная почва. Они являются основными неклиматическими факторами, влияющими на водные процессы в лесных экосистемах. Было исследовано влияние изменения пользования землей на прямой сток в лесных бассейнах. Для этого было применено гидрологическое моделирование. Модель стока была сформирована как каскад линейных резервуаров. Модель отделения осадков основывалась на методе SCS-CN, немного измененном в зависимости от уникальной методики. Самые большие усилия были сконцентрированы на получении методического решения. Модель была проверена в бассейне низменного леса, который простирается в польской части Центрально-европейской равнины. Модель была откалибрирована с учетом современного состояния покрова земли на основании девяти предполагаемых сценариев, а также случая, если бы был восстановлен исторический покров земли. Состояние покрова земли было описано в соответствии с количественными и/или качественными изменениями свойств растительности.

Ключевые слова: моделирование дождя-стока, прямой сток, метод SCS-CN, лесной бассейн, изменение покрова земли.

Bernard OKOŃSKI. PhD, Assistant Professor (since 2004), Dept of Forest Engineering, Agricultural University in Poznań, Poland.

PhD, AUP, 2004. Publications: author of 25 research papers. Research interests: rainfall-runoff modeling, impact of drought on forest ecosystems, hydrology of marshlands. Membership: International Association of Hydrological Sciences (IAHS). 